JELTIS: Journal of English Language Teaching, Linguistics and Literature Studies

Volume 1. Number 1. August 2021

Available at http://journal.iain-manado.ac.id/index.php/jeltis/index

\title{
A Grammatical and Semantic Non-Equivalence Analysis of Cinderella Text Translation
}

\author{
Hapni Nurliana H.D Hasibuan \\ Universitas Negeri Yogyakarta, Yogyakarta, Indonesia \\ hapnihasibuan@gmail.com
}

\begin{abstract}
A grammatical and semantic non-equivalence analysis of Cinderella text translation. This research's aims to determine the grammatical non-equivalence in the translation of English and Indonesian in Cinderella texts. This research is based on Baker's theory of grammatical equivalence (1992) and Nida \& Taber's about semantic equivalence (1982). The research method used is a mixed method (quantitative-qualitative). Quantitative methods are used to classify grammatical and semantic incompatibility categories while the qualitative methods are on the content analysis approach. The results showed that Cinderella text has nonequivalence translation in Grammatical such: number, persona, gender, and tense and semantic is lost meaning and the meaning changes.
\end{abstract}

Keywords: translation, grammatical equivalence, semantic equivalence, short story, Cinderella

\section{Introduction}

The main concept of translation is the effort to reproduce the source text (ST) with an equivalent text in the target text (TT). In other words, translation is translating TT text into ST text with an equivalent meaning. This opinion is supported by the following expert opinion. Catford (1969: 20) argues that translation is "the replacement of textual material in one language (SL) by equivalent textual material in another language $(T L)$ " (replacing textual material in TT with equivalent textual material in ST. Newmark (1988: 7) attempts that translation is to replace a written message and / or statement in one language by the same message and / or statement in another language. Third, in more detail, Larson (1988)says that translation are (1) studying lexicons, structures grammatical, communicationituations and cultural contexts of the TT text; (2) analyzing the source text to find its meaning; and (3) re-expressing the same meaning using lexicons and the appropriate grammatical structure in the ST and its cultural context. 
JELTIS: Journal of English Language Teaching, Linguistics and Literature Studies Volume 1. Number 1. August 2021

Available at http://journal.iain-manado.ac.id/index.php/jeltis/index

Translation contains reproduction into the target language which is as natural as possible in terms olf meaning and style (Nida \& Taber, 1982). The translation process is an activity that requires the translator's knowledge and skills, because the words, phrases, and discourse that are translated are not only at the level of the language, but also at the level of discourse, which refers to their function. From the definitions and directions above, it can be concluded that the main points of translation are as follows, (1) translation involves two languages, namely the source language (TT) and the target language (ST) and the two languages must be mastered by the translator, (2) the translation text must contain the same meaning (message), tone and style as the original text but be expressed through the ST structure.

The main problem in translation is obtaining a correspondence between the ST to be translated and the TT that is the result of the translation process. The equivalence between $\Pi$ and ST is seen in terms of form and content. The equivalence problem arises because of differences in grammatical, semantic, sociocultural systems between the ST and the TT. Further, as the essence of translation, the search for equivalents will lead to the concept of translation and un-translation (Nababan, 2008).

This is reinforced by Catford's (1965: 21) statement "the central problem of translation practice is that to find the TT translation equivalence". The equivalence in translation means how to signal the information conveyed in both the ST and the TT so that both have similarities at certain levels (Munday, 2016: 69; Panou, 2013: 2; Pym, 2014: 2). A translator should be able to find the closest correspondence to certain linguistic units in the ST to be translated into linguistic units in the TT.

There are several studies that have been done regarding translation equivalence. A research which conducted by Rosmawati (2015), showed that the translator does not completely eliminate the meaning of the ST (Indonesian), it can be seen from the missing meaning score of only $2.4 \%$. The translator transfers the meaning of the source text well, this can be seen based on the results of full meaning data (MP) of $84.7 \%$. In addition, Mardiana (2014) described that in My Beloved Edith short story found some shifting: structure shifting, unit shift, category shift and active point of view shift in SL to passive in TL. These shifts were caused by transposition and modulation techniques. 
JELTIS: Journal of English Language Teaching, Linguistics and Literature Studies Volume 1. Number 1. August 2021

Available at http://journal.iain-manado.ac.id/index.php/jeltis/index

Based on the explanation of previous studies, there were some shifts in short story translation. However, it becomes the main problem of a translation. The translator did not find the equivalent word in the TT thus s/he do the shifts. As the crucial problems in translation, the non-equivalence becomes the gap in the area of equivalence. Therefore, this research focuses on the non-equivalent translation. To conduct the analysis, the research used Grammatical equivalence Baker's (1992) and semantic equivalence of Nida's theory (1982).

One of categories in translation studies is literary work. The short story 'Cinderella text' is one of literary work. This short story will be used in this analysis. this research question is "Is there any non-equivalence translation in Cinderella Text? Grammatical or semantic non-equivalence?"

\section{Methodology}

This research used mixed methods which is a research step by combining two forms of research approaches, namely qualitative and quantitative. Mixed research is a research approach that combines qualitative research with quantitative research (Creswell, 2010: 5). The quantitative method is the first research method used to process or calculate the results of the grammatical and semantic mismatch categories in the Cinderella translation text.

This research also uses a qualitative approach with the content analysis method with descriptive recording / coding units to obtain translation errors and non-equivalence in the Cinderella short story. The research data collection instrument was a human instrument. "Qualitative research places researchers as a key instrument" (Creswell,2013: 261). Researchers have the performance and competent in Indonesian and English and have knowledge in translation.

The data collection technique is observation and taking-note method with the process of reading and re-reading the contents of Cinderella's text, recording or copying data by rewriting the text according to each language, grouping data in the form of TT according to the ST in the column provided, double-check so that each text fits in its column. The data taken is at the linguistic level which includes words, phrases and sentences, that experience non-equivalence in translation.

The data analysis technique is data reduction, the data selected is data that is not equivalent between the ST and TT. The data collection will be reduced and 
JELTIS: Journal of English Language Teaching, Linguistics and Literature Studies Volume 1. Number 1. August 2021

Available at http://journal.iain-manado.ac.id/index.php/jeltis/index

classified based on the dimensions of the grammatical and semantic equivalence then described in the findings and discussion.

\section{Findings}

The non-equivalence of grammatical in the TT.

Based on the text in Cinderella's text, the researcher found 9 grammatical non-equivalence either in the form of words, phrases or clauses. The analysis was carried out based on Baker's (1992) theory as shown:

Table 1. Frequently of Grammatical Non-equivalence

\begin{tabular}{clcc}
\hline No. & \multicolumn{1}{c}{$\begin{array}{c}\text { Grammatical Non- } \\
\text { equivalence }\end{array}$} & Frequently & $\%$ \\
\hline $\mathbf{1}$ & Number & 1 & $(11 \%)$ \\
$\mathbf{2}$ & Gender & 4 & $(44 \%)$ \\
$\mathbf{3}$ & Persona & 2 & $(22 \%)$ \\
$\mathbf{4}$ & Tense and Aspect & 2 & $(22 \%)$ \\
\hline & Total & 9 & $(100 \%)$ \\
\hline
\end{tabular}

The table above shows the frequency of any grammatical non-equivalence that appear in the translation of the Cinderella text. There are 4 out of 5 categories that refer to Mona and Baker's theory of grammatical equivalence. Researchers found 9 grammatical discrepancies in the translation of the Cinderella text. Based on the table above, it can be concluded that the most dominant gender category is found in the Cinderella translation, which is 4 data (44\%). The number category is very rare, only 1 data (11\%).

The results of the analysis of Cinderella's text in English found that 40 sentences were further analyzed in terms of the equivalence that occurred in the translation. Following are the results of the equivalence and un-equivalence found in the Cinderella text.

\section{The non-equivalence of semantic in the TT}

The analysis is based on Nida's theory developed by Rosmawati (2015) which divides semantic equivalence into 2 categories, namely equivalence and nonequivalence. In semantic equivalence it consists of three categories, namely complete meaning, increase meaning, decrease meaning. The meaning of disagreement is divided into two categories, namely, missing meaning and different 
JELTIS: Journal of English Language Teaching, Linguistics and Literature Studies Volume 1. Number 1. August 2021

Available at http://journal.iain-manado.ac.id/index.php/jeltis/index

meaning. The results of the appearance of the meaning of equivalence can be seen in the following table.

Table 1. Frequently of the Semantic Equivalence

\begin{tabular}{cccc}
\hline & Semantic Equivalence & Frequently & $\%$ \\
\hline $\mathbf{1}$ & Complete & 12 & $30 \%$ \\
& Meaning & & \\
$\mathbf{2}$ & Increase meaning & 4 & $10 \%$ \\
$\mathbf{3}$ & Decrease meaning & 4 & $10 \%$ \\
\hline & Semantic Non-equivalence & & \\
\hline $\mathbf{1}$ & Missing meaning & 6 & $15 \%$ \\
$\mathbf{2}$ & Different meaning & 14 & $35 \%$ \\
\hline & Total & 40 & $100 \%$
\end{tabular}

From the data above, it can be seen that the appearance of the meaning is equivalent to the category of complete meaning which is 12 or 30\%, the meaning of increasing is 4 times the appearance or $10 \%$, the meaning of decreasing is 4 times or 10. \%. The non-equivalent meaning category consists of missing meaning and different meaning. For the category of missing meaning, which is 6 times or $15 \%$, different meaning is 14 times or $35 \%$.

\section{Discussion}

Translation is the process of transferring the ST to the TT. In the translation process, problems often arise, one of which is a non-equivalence. In accordance with Baker's (1992) theory, differences in the grammatical structure of the ST and TT often result in some changes in the information content of messages during the translation process. This change may result in additions to the TT that are not expressed in the ST.

Data (1)

ST: The Prince, who was now madly in love with her, picked up the slipper and said to his ministers, "Go and search everywhere for the girl whose foot this slipper fits

TT: Pangeran, yang sekarang jatuh cinta dengan dia, mengambil sepatu itu dan berkata kepada menterinya, "Pergi dan cari di mana pun gadis yang kaki nya cocok dengan sandal ini.

The data above shows a grammatical mismatch of the amount category. The results of the translation on the plural number in English can be marked with $-\mathrm{s}$, while in Indonesian the plural can be marked by repeating the word or adding 
JELTIS: Journal of English Language Teaching, Linguistics and Literature Studies Volume 1. Number 1. August 2021

Available at http://journal.iain-manado.ac.id/index.php/jeltis/index

several or more preceding words. From data 1, there are 2 words that have a reduced semantic mismatch in the meaning category. (1) ministers, the context of the Cinderalla text is kingdom. So, it's best if the ministers are translated by the guards. (2) the word translated slipper as sandal. This translation is less than commensurate in meaning. When viewed in the context of the text, the appropriate translation result is glass slipper.

Data (2):

ST You have something neither of your stepsisters has and that is beauty.

TT: Percayalah kamu memiliki sesuatu yang saudara tiri mu tidak memilikinya dan itu adalah kecantikanmu.

According to Baker (1992), gender is a noun classified as masculine and feminism. This difference refers to both living things and non-living objects. e word stepstisters is translated as brother. While in Indonesian, brother is masculine which refers to someone who has a relationship with a man. The translation results above are included in the category not commensurate with the meaning reduced.

Data (3),

ST: You? You're staying at home to wash the dishes

TT: Kamu? Kamu tetap tinggal di rumah untuk mencuci piring

The above data shows a gammatical mismatch at the persona level. In line with Baker's theory and added by Ezmir (2015: 49) the dimensions of familiarity in the pronoun system are among the aspects of grammar which are the most interesting and the most problematic in translation. In the sentence above, the familiar relationship between a stepmother's words to Cinderella, who is her stepson. This familiar dimension requires that the word you choose between you or you in a single second persona. The word that is more suitable in translating the word you is you. However, there is a full synonym for semantics. This can be seen from the translation of the word you in the TT is you.

Data (4),

ST: The Prince is waiting for you

TT: Pangeran telah menunggu anda

The data above shows the grammatical mismatch of tense. The verb is waiting in the ST identifies being in progress (continuous), while the TT is translated 


\section{JELTIS: Journal of English Language Teaching, Linguistics and Literature Studies Volume 1. Number 1. August 2021}

Available at http://journal.iain-manado.ac.id/index.php/jeltis/index

waiting. However, this sentence is commensurate in meaning and can be accepted. The meaning of waiting in the TT means that he has been and is still waiting.

Data (5),

ST: Her stepmother didn't like her one little bit. But, for the poor unhappy girl, there was nothing at all.

TT: Ibu tiri nya tidak suka sedikit pun dengannya. Seluruh kasih sayang nya hanya untuk anak nya sendiri.

The data above is equivalent in grammatical terms. However, it is not worth it in terms of semantics. There is a reduction in the meaning of the sentence But, for the poor unhappy girl, there was nothing at all. When it comes to pragmatic equivalence, the translation in the TT is already commensurate. The implicature of a stepmother that is identical to not loving her stepdaughter, so it is replaced with all her affection for her own child.

Data (6),

ST: It was quite true. Cinderella, even dressed in old rags, was a lovely girl.

TT: Cinderella berpakaian compang-camping

The data above is included in the category of sentences that are not equivalent / non-equivalent because the meaning is lost, there is an omission of the meaning of the TT (Indonesian), which is in the form of not being translated into the ST in the TT / missing sentences.

Data (7),

ST: While her stepsisters, no matter how splendid and elegant their clothes, were still clumsy, lumpy and ugly and always would be.

TT: Sementara saudara tiri nya tidak peduli dengannya. Betapa indah dan elegan pakaian mereka.

In connection with the equivalence in translation, the translation in the TT above found the omission of meaning in the sentence were still clumsy, lumpy and ugly and always would be. However, in terms of pragmatic equivalence it is worth it. This can be seen by adding phrases no matter what. In line with the definition of pragmatic equivalence, namely equivalence that includes coherence, implicature (Baker, 1992).

Data (8)

ST: Only when evening came was she allowed to sit for a while by the fire, near the cinders. 
JELTIS: Journal of English Language Teaching, Linguistics and Literature Studies Volume 1. Number 1. August 2021

Available at http://journal.iain-manado.ac.id/index.php/jeltis/index

TT: Hanya ketika malam tiba dia diperbolehkan untuk duduk untuk sementara waktu oleh api, dekat abu.

From the data above, it can be seen that there are meanings that are not equivalent / non-equivalent with different meaning categories (MB). The ST says that for a while by the fire, near the cinders is translated to temporarily by fire, near ashes. The translation carried out by the translator is to use literal translation, which is translating words for words, where this procedure seeks to interpret each word in the ST sentence and adjust it to the rules of the TT of Vinay and Darbenet in Munday (2001). If the meaning has not been conveyed, it is necessary to apply other methods. In line with this understanding, disproportionate and unacceptable data in the TT are disproportionate and unacceptable. Acceptability and readability can be seen from the usual translation and can be easily understood by readers.

The main problem with translation is finding a correspondence between the ST and the TT. Translation non-equivalence are often found in the translation results. This research focused on analyzing grammatical and semantic nonequivalence. There are several discrepancies found in Cinderella text, such as: there are words/phrases that are not-equivalent grammatical but equivalent semantics.

\section{Conclusion}

Regarding to the result of the research, it draws the conclusions that Cinderella has 4 non-equivalent grammatical categories, namely number, persona, gender, and tense. Gender is the most frequent. Furthermore, the semantic nonequivalence in the Cinderella text is lost and the meaning changes. These categories have quite a lot of disaggregated data. This is due to differences in grammar in the TT and ST as well as differences in meaning in the two languages. Therefore, the Cinderella text is not completely equivalent in translation.

\section{References}

Baker, Mona. (1992). In other words: a coursebook on translation. London Routledge. Catford. J. C. (1965). A linguistic Theory of Translation. Oxford: Oxford University Press

Creswell, W. J. (2013). Research design pendekatan kualitatif, kuantitatif, dan mixed (edisi ketiga). (Terjemahan Achmad Fawaidi). Yogyakarta: Pustaka Pelajar. (Edisi asli diterbitkan tahun 2009 oleh SAGE Publiscations. Thousand Oaks 
JELTIS: Journal of English Language Teaching, Linguistics and Literature Studies

Volume 1. Number 1. August 2021

Available at http://journal.iain-manado.ac.id/index.php/jeltis/index

California).

Larson, Mildred L. (1988). Meaning Based Translation: Penerjemahan Berdasar Makna. Penerbit Arcan.

Mardiana, Wiwik (2014). Teknik Transposisi Dan Modulasi: Kesepadanan Dan Pergeseran Dalam Penerjemahan Cerpen Berjudul "My Beloved Edith". Journal Parole Vol.4 No.2, October 2014.

Munday, J. (2016). Introducing Translation Studies: Theories and Applications (4thed.).

Nababan, M.R. (2008). Teori Menerjemah Bahasa Inggris. Yogyakarta: Pustaka Pelajar.

Nida, E. A. \& Taber. (1982). The Theory and Practice of Translation. Leiden: E. J.

Brill.Panou, D. (2013). Equivalence in Translation Theories: A Critical Evaluation, 3(1), 1- 6. https://doi.org/10.4304/tpls.3.1.1-6

Rosmawati, Deci. (2015). Analisis Penerjemahan Kesepadanan Teks Bilingual "Pak Banjir Bertaubat" Karya Dhanu Priyo Prabowo Dan "Mr. Banjir Repetance" Karya Abdur Rosyid. Indonesia Jurnal of Applied Linguistic review, Vol 1, No.2 